\title{
Stable Triplet of Uracil-Uracil Basepairs in a Small Antisense RNA
}

Yiping Zhan and Gordon S. Rule*

Department of Biological Sciences, Carnegie Mellon University, 4400 Fifth Ave, Pittsburgh, PA, 15213

A B

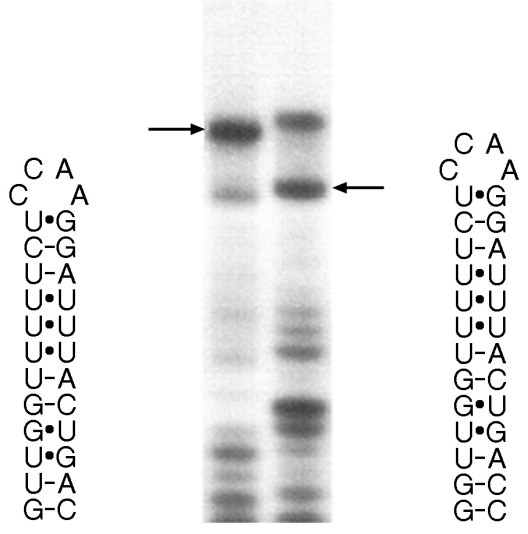

Figure 1. Autoradiography of a PAGE gel showing transcription products using templates for the first hairpin of sar without (lane A) and with (lane B) the extra GC pair. The arrows indicate the products that were optimized for yield and purified. Mass spectrometry showed that the products from lane A and B are $45 \mathrm{nt}$ and 30nt, respectively. The product in lane B is the expected size for the first hairpin with an extra GC pair. The expected RNA sequence from each transcription reaction is shown adjacent to the gel lane.

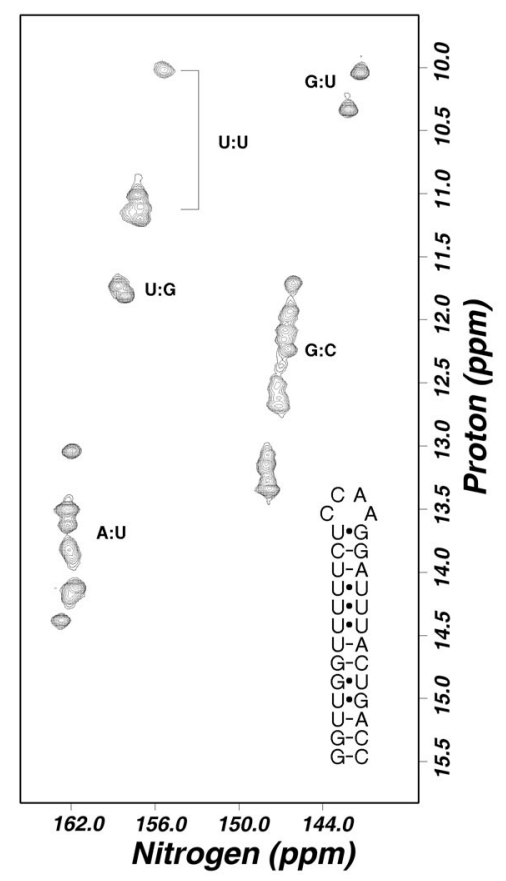

Figure 2. HSQC spectrum showing the imino region of the first hairpin of sar (the $30 \mathrm{nt}$ transcript in lane B of Figure 1). The labels indicate the location of imino resonances from various types of basepairs.

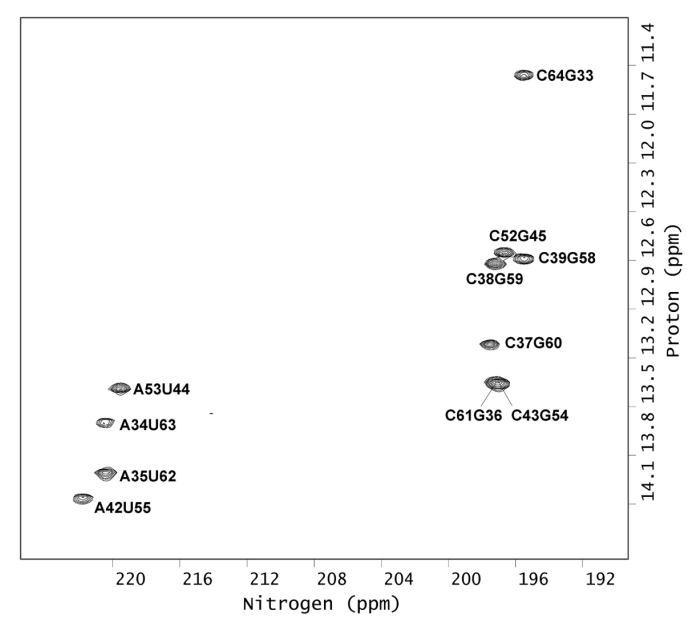

Figure 3. Long-range HMQC spectrum of the isolated second hairpin of sar showing peaks generated by $\mathrm{N}-\mathrm{H}^{\cdots} \mathrm{N}$ hydrogen bonds. The numbering of the assignments are according to whole sar RNA. The ${ }^{15} \mathrm{~N}$ carrier frequency and sweep width were $187 \mathrm{ppm}$ and $106 \mathrm{ppm}$, respectively. 160 complex points were collected for the ${ }^{15} \mathrm{~N}$ dimension.

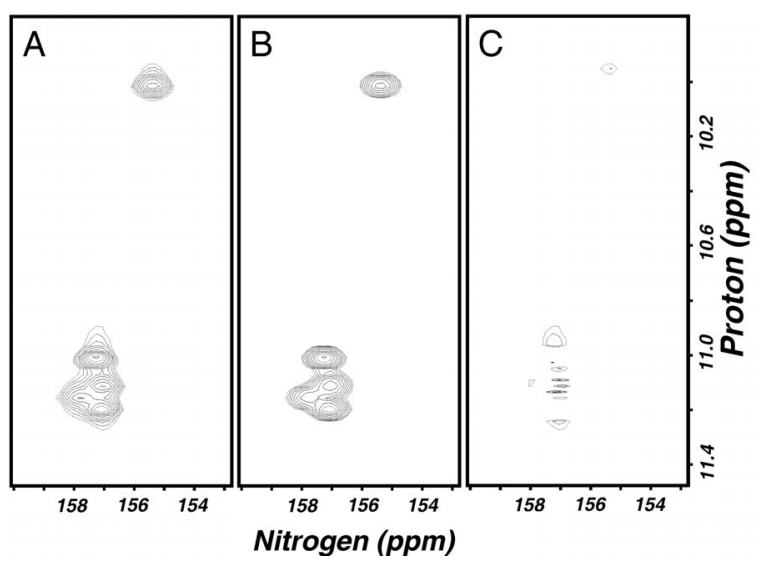

Figure 4: Peak fitting of the U:U imino proton region. Panel $A$ is the experimental spectrum. Panel B shows the simulated spectrum. Panel C shows the residual in the fit. Assuming that the peak at $\delta_{\mathrm{N}}=155, \delta_{\mathrm{H}}=$ 10.00 corresponds to 1 proton, the region of the spectrum at $\sim \delta_{\mathrm{H}}=11$ integrates to a relative intensity of 4.98 , giving a total of 6 protons for this region of the spectrum. 


\section{Methods:}

Double-stranded DNA template preparation for the whole sar: Restriction enzyme-digested plasmid DNA was used as template for preparing whole $\operatorname{sar}^{1,2}$. To construct plasmid pUC19sar, add-on PCR was performed using the plasmid $p G E M-2 s c^{3}$ as template to add a restriction site for HindIII and the 17-nt T7 promoter to the 5' end of the sar sequence and a DraI site and a EcoRI site to the 3' end of the sequence. This PCR product was digested with both HindIII and EcoRI and cloned into pUC19, resulting in pUC19sar. This plasmid, when digested with DraI, gives a double-stranded DNA template for in vitro transcription by T7 RNA polymerase for the whole sar.

Milligrams of pure $p U C 19$ sar plasmid was prepared from E. coli JM109 using CsCl-ethidium bromide gradient methods ${ }^{4}$. In a typical large-scale digest of pUC19sar, the reaction volume was approximately $25 \mathrm{ml}$, with $0.05 \mathrm{mg} / \mathrm{ml}$ plasmid, $30 \mathrm{u} / \mathrm{ml}$ restriction enzyme, $0.1 \mathrm{mg} / \mathrm{ml}$ BSA in the appropriate buffer for the specific restriction enzyme. The reaction was incubated at $37^{\circ} \mathrm{C}$ with occasional gentle mixing. Although the reaction was usually complete within a few hours, the digest was allowed to go for 24 hours before phenol/chloroform extraction and ethanol precipitation to recover the DNA template for transcription.

NMR sample preparation: ${ }^{15} \mathrm{~N}$-labeled RNA molecules were prepared using large-scale run-off in vitro transcription by T7 RNA polymerase ${ }^{5}$. A modified version of a published T7 RNA polymerase purification protocol ${ }^{6,7}$ was followed. The major modification was that five $0.9 \mathrm{ml}$ peak fractions were pooled for the S-Sepharose FF column. Uniformly ${ }^{15} \mathrm{~N}$-labeled NMPs were produced using the protocol published by Batey et $\mathrm{al}^{8}{ }^{8}$ and the procedure described by Nikonowicz et al. ${ }^{9}$ was used for the conversion of NMPs to NTPs.

Digested plasmid was used as template for whole sar, while single-stranded DNA with a double-stranded T7 promoter region was used for the separate hairpins of sar. The first hairpin with an extra GC pair at the end of the stem (subsequently simply called "the first hairpin") was used as a model for the isolated first hairpin because the extra GC pair reduced the level of an aberrant transcript produced by in vitro transcription reactions.

The transcription reactions contained $40 \mathrm{mM}$ Tris $\cdot \mathrm{HCl}$ pH8.1, $0.01 \%$ Triton X-100, $1 \mathrm{mM}$ spermidine, and $5 \mathrm{mM}$ DTT. The reaction for synthesis of the first hairpin of sar also contained: $7.5 \mathrm{mM} \mathrm{MgCl} 2,100 \mathrm{nM}$ of DNA template oligonucleotides, $2.5 \mathrm{mM}$ of each NTP, $0.25 \mathrm{u} / \mathrm{ml}$ inorganic pyrophosphatase (IPP) ${ }^{10}$, and $0.01 \mathrm{mg} / \mathrm{ml}$ T7 RNA polymerase in a total volume of $70 \mathrm{ml}$. The reaction for preparing the second hairpin of sar contained: $16 \mathrm{mM}$ $\mathrm{MgCl}_{2}, 100 \mathrm{nM}$ of DNA template oligonucleotides, $3 \mathrm{mM}$ of each NTP, $80 \mathrm{mg} / \mathrm{ml}$ PEG8000, and $0.11 \mathrm{mg} / \mathrm{ml}$ T7 RNA polymerase in a total volume of $19 \mathrm{ml}$. The reaction for preparing whole sar contained: $12 \mathrm{mM} \mathrm{MgCl}_{2}, 0.1 \mathrm{mg} / \mathrm{ml}$ DraI-digested pUC19sar, $3 \mathrm{mM}$ of each NTP, $0.2 \mathrm{u} / \mathrm{ml} \mathrm{IPP,}$ and $0.01 \mathrm{mg} / \mathrm{ml}$ T7 RNA polymerase in a total volume of $24 \mathrm{ml}$. In all cases, the reactions were incubated for 4-6 hours at $37^{\circ} \mathrm{C}$. The desired RNA product was purified by denaturing PAGE gel. Final yields of purified ${ }^{15} \mathrm{~N}$-labeled
RNA were $0.010 \mathrm{mg} / \mathrm{ml}$ for the first hairpin, $0.15 \mathrm{mg} / \mathrm{ml}$ for the second hairpin, and $0.073 \mathrm{mg} / \mathrm{ml}$ for intact sar.

In spite of extensive optimization of the transcription reaction, by varying template, $\mathrm{Mg}^{2+}$, and polymerase concentrations, the yields for the first hairpin and intact sar could not be improved.

NMR Spectroscopy: All NMR experiments were performed at $298 \mathrm{~K}$ on Bruker DRX spectrometers. The proton carrier was placed on water and a proton sweep width of 22.04 ppm (1024 complex points) was used for all experiments. HMQC experiments for observing the imino-amino regions used a ${ }^{15} \mathrm{~N}$ carrier frequency and sweep width of $118 \mathrm{ppm}$ and $100 \mathrm{ppm}$, respectively. The recycle delay between scans was about $1.2 \mathrm{~s}$. The number of scans for each free induction decay (FID) varied between 16 (e.g. HSQC) and 64 (e.g. long range HSQC). The 3D-NOESY spectra were acquired with 150 complex points and a sweep width of 12 ppm for the indirectly detected proton dimension. The number of complex points and the sweep width for the ${ }^{15} \mathrm{~N}$ dimension of the 3D-NOESY experiment were 32 and $100 \mathrm{ppm}$, respectively. Each FID contained 16 scans.

MALDI-TOF Mass Spectrometry:

Approximately $1 \mathrm{nmol}$ of lyophilized RNA was dissolved in $40 \mu \mathrm{l}$ of $75 \mathrm{mg} / \mathrm{ml} \mathrm{3-hydroxypicolinic} \mathrm{acid} \mathrm{solution} \mathrm{in}$ water:acetonitrile (1:1). Dowex cation exchange beads in the $\mathrm{NH}_{4}{ }^{+}$form were added to the RNA solution to remove other cations that may affect the performance of mass spectrometry ${ }^{11}$. About $1 \mu \mathrm{l}$ of RNA solution was spotted on a gold surface plate for MALDI-TOF mass spectrometry using a PerSeptive Voyager STR mass spectrometer. Both the positive and the negative ion mode worked well for molecular weight determination.

\section{References:}

1. Szewczak, A.A., White, S.A., Gewirth, D.T. , Moore, P.B. Nucleic Acids Res. 1990, 18, 4139-4142.

2. Dallas, A., Rycyna, R. and Moore, P. Biochem. Cell Biol. 1995, 73, 887-897.

3. Liao, S. M. 1988 Thesis: Regulation of gene expression in the immunity I region of bateriophage P22. Pittsburgh, Pennsylvania, Carnegie Mellon University.

4. Sambrook, J. and Russell, D.W. 2001, Molecular Cloning: A Laboratory Manual. $3^{\text {rd }}$ ed. Cold Spring Harbor Laboratory Press, Cold Spring Harbor, New York.

5. Milligan, J.F. and Uhlenbeck, O.C. Meth. Enzymol. 1989, 180, 51-62.

6. Grodberg, J. and Dunn, J.J. J. Bacteriol. 1988, 170, 1245-1253.

7. Zawadzki, V. and Gross H.J. Nucleic Acids Res. 1991, 19, 1948

8. Batey, R.T., Battiste, J.L. and Williamson, J.R. Meth. Enzymol. 1995, 261, 300-322.

9. Nikonowicz, E.P., Sirr, A., Legault, P., Jucker, F.M., Baer, L.M. and Pardi, A. Nuc. Acids Res. 1992, 20, 4507-4513.

10. Gregorian, R.S. Jr. and Crothers, D.M. J Mol Biol. 1995, 248, 968-984.

11. Ball, R.W. and Packman, L.C. Analytical Biochem. 1997, 246, 185-194. 